13 - Technical skill

\title{
Infrared coagulation: a preferred option in treating early hemorrhoids ${ }^{1}$
}

\author{
Pravin J.Gupta ${ }^{2}$
}

\begin{abstract}
Gupta PJ. Infrared coagulation: a preferred option in treating early hemorrhoids. Acta Cir Bras [serial online] 2004 Jan-Feb;19(1). Available from URL: http://www.scielo.br/acb

ABSTRACT - Background: The ideal therapy for hemorrhoids is always debated. For early grades of the disease, many different modalities of treatment have been proposed. Some are effective but are more painful, others are less painful but their efficacy is not assured on long term. Infrared photocoagulation has emerged as a new addition to the list. In this procedure, the tissue is coagulated by infrared radiation. During treatment, mechanical pressure and radiation energy are applied simultaneously to ablate the blood supply to the hemorrhoidal mass. Methods: In the present retrospective study, the effect of infrared coagulation on patients with early grades of hemorrhoids is described. In a separate study, a comparison is made between Infrared coagulation and rubber band ligation in terms of their effectiveness and discomfort. Results: 212 patients were treated by infrared coagulation and were followed up for a period of 18 months. Only 28 patients had persistence or recurrence of bleeding. Overall ratio of comfort and patient satisfaction from pain and bleeding was quite satisfactory. The comparative study showed that though rubber band ligation is more effective, it is a more painful procedure. Conclusion: These studies shows that Infrared coagulation for hemorrhoids in early stages could prove to be a easy and effective alternative to conventional methods as it is quick, less painful and safe. The procedure can be repeated in case of recurrence and should be considered as the first choice in early hemorrhoids.
\end{abstract}

KEY WORDS - Hemorrhoids. Infrared rays. Hemostatics. Patient-focused care. Ambulatory surgical procedures.

\section{Introduction}

Hemorrhoids or piles are a very common pathology. It is found in almost $50 \%$ of the people over the age of fifty who suffer from the disease in some or other form ${ }^{1}$. Many options have been put forth and tried ${ }^{2}$ for the treatment of this ancient disease. In modern times, a fast and painless procedure that could be carried out in the office practice under local anesthesia will surely be preferred and accepted $^{3}$. Infrared photocoagulation [IRC] is found to fit the bill. It was introduced in late seventies by $\mathrm{Nath}^{4}$. In infrared contact coagulation, the tissue is coagulated not by means of an electric current, but through an infrared radiation ${ }^{5}$. During treatment, mechanical pressure and radiation energy are applied simultaneously in a manner that eliminate the disadvantages of electro coagulation like grounding the patient, charring of the tissues which causes extensive and unpredictable lateral damage leading to subsequent fibrosis. There is an obvious risk of electric current passing through the body with the use of electrocoagulation, which may cause painful muscular spasms ${ }^{6}$. IRC, on the other hand, being free from these hazards, has proved to be an effective and safe method of treatment for early grade bleeding internal hemorrhoids ${ }^{7}$. We are using the infrared coagulator from LUMATEC, Munchen, Germany. A light guide of $220 \mathrm{~mm}$ with a tip diameter of $6 \mathrm{~mm}$ is being used for the process of coagulation.

\section{Aim of the study}

The motto behind this study was to show that IRC is an effective, safe, and less painful alternative when compared to other modalities in vogue for treatment of early degree of bleeding hemorrhoids. The other treatment procedures in use are - 1] Employing rubber band ligation.
2] By chemical destruction of pile mass with sclerotherapy or direct current probe [Ultroid].

3] Procedures involving thermal destruction of hemorrhoids like bipolar diathermy [Bicap] or cryoablation.

\section{Methods}

In the present retrospective study, the effect of infrared coagulation on patients with hemorrhoids was observed over a follow up period ranging from 12 to 18 months. In all, 212 patients were treated with infrared coagulation. This included 126 males and 66 females. The mean age of the patients was $34 \mathrm{yrs}$. [Range between 19 and 69 yrs]. The study was conducted at Gupta Nursing Home, Nagpur-India, between July 1999 and June 2000.

The diagnosis of hemorrhoids was made on anoscopic examination and patients having first and second degree ${ }^{8}$ bleeding

1. Article from Gupta Nursing Home, Nagpur-India.

2. M.S [Gen.Surgery], Consulting Proctologist. 
hemorrhoids were selected for the procedure. 97 of the patients were having grade I hemorrhoids. Remaining 115 patients had Grade II hemorrhoids which used to prolapse during defecation and getting reduced by their own. 107 of the patients from the study have failed to respond to conservative treatment given in the past.

\section{Exclusion criteria}

Patients having associated anal fissure or infective anal pathologies like cryptitis or proctitis were excluded from the study. Similarly, patients who had not signed the informed consent and pregnant women with less than 12 weeks' pregnancy were excluded from the study.

All the patients received written explanation of the technique including potential drawbacks, such as relapses and a possible need for a repeat or a resort to other mode of treatment. The procedure was approved by the local ethical committee and was performed according to the declaration of Helsinki.

In this procedure, no anesthesia was given. However, 5\% xylocain ointment was generously applied in the ano-rectum 10 minutes prior to the actual procedure, to reduce the sensitivity of the area.

\section{Procedure of infrared coagulation}

The procedure was performed keeping the patients in left lateral position.

Hemorrhoids were visualized by inserting the anoscope. The operative field was cleaned to obtain a clear view of the area. The base of the pile was traced. It was ensured that the edge of the anoscope is positioned above the dentate line to minimize pain or discomfort. Two or three linear spots of coagulation were made touching the tip of the light guide firmly over the pedicle. A burst of radiation in a cloverleaf fashion to the base of each of the three principal hemorrhoidal cushions was sufficient. The timer of the coagulator was set to 2 seconds, which approximately attained coagulation to a depth of $2 \mathrm{~mm}$ of the area. A white round spot appearing at the place of application indicated completion of the coagulation.

Care was taken to ensure that the spots of application do not overlap, as this could

lead to an excess amount of tissue destruction.

All the pile bases were coagulated one after the other. There was no special preference for the positions of hemorrhoids to begin with; though we went on dealing with the largest pile first and so on. The mean treatment duration was 3 minutes, having ranged between 2 to 5 minutes.

The patients were allowed to go home and were advised to resume to their routine activities. A regular dose of laxative was

prescribed. They were asked to apply a 5\% Xylocain ointment before and after defecation to relieve the post defecation discomfort and the possible burning sensation. They were cautioned not to stain at stool and that they should expect little bleeding in the first few days.

\section{Observations}

The patients were called for follow up after 4 weeks of the procedure. The findings are given in Table 1.

TABLE 1 - Observations in the first four weeks from patients subjected to infrared coagulation of the hemorrhoids

\begin{tabular}{l|c}
\multicolumn{1}{c|}{ COMPLAINTS } & NO.OFPATIENTS \\
\hline Bleeding [Slight with stool] & 23 \\
Bleeding [Heavy] & 4 \\
Pain [Local] & 27 \\
Discharge & 3 \\
Itching & 11 \\
Retention of urine & 2 \\
\hline
\end{tabular}

1] 23 of the patients [10.8\%] complained of bleeding in first 4 weeks. This most frequently occurred between day 5 and day 10 of the procedure. The bleeding was associated with defecation. This was attributed to sloughing of the tissue at the base of hemorrhoids and oozing from the raw area thus created.

However, 4 patients [1.8\%] had returned back with heavy bleeding in the first week of the procedure. This bleeding was spontaneous, unassociated with defecation. They were readmitted. 3 of them responded to conservative therapy in the form of local compression and haemostatic medication. One patient needed examination under general anesthesia. The active bleeding source was secured. None of them reported with any bleeding thereafter.

2] 27 patients complained of pain in the anal region. The intensity of pain was 1 to 2 on visual analogue scale. They were prescribed appropriate analgesics. Rest of the patients did not complained of any pain. 3 ] 3 patients [1.5\%] complained of a brownish, foul smelling discharge from rectum. This was noticed at the end of the first week of the procedure. While the exact cause of this discharge could not be determined, it could perhaps be due to shedding of the dead mucosa over the pile.
No specific treatment was advocated. The discharge ceased of its own by the end of second week of the procedure.

4] 11 patients [5\%] had a complaint of itching in and around the anal canal. The itching stopped in a few days of its own.

\section{Follow up}

The second follow up was carried at a mean of 18 months [range 15-20 months] of the procedure. The observations were as follows.

9 patients [4\%] lost to follow up.

\section{Bleeding}

During this period, 28 patients had recurrence of bleeding. 4 patients refused to undergo repeat procedure. In the remaining 24 patients, the procedure had to be repeated. 3 of them continued to have bleeding even after the second sitting of coagulation. They were subjected to band ligation. In the remaining, no bleeding was reported.

\section{Pain}

None of the patients had any pain in the anal region. A few complained of minor 
discomfort during defecation. On being implored, the discomfort was found relatable to their faulty dietary habits. They were instructed to follow regularity in their diet and to strictly avoid spicy and pungent food. The cause being extraneous, no specific medication was prescribed.

Comparison of infrared coagulation and band ligation

A separate comparative study was conducted at Gupta Nursing Home, Nagpur-India, between July, 2000 and March 2001 to find out the effect of infrared coagulation [IRC] and rubber band ligation [RBL] on the hemorrhoids. consecutive patients of $2^{\text {nd }}$ degree bleeding hemorrhoids were randomly chosen. It was irrespective of age, sex, and duration of disease or previous treatment. Infra Red Coagulation [IRC] was done in 48 patients and the remaining 52 patients were treated with Rubber Band Ligation [RBL]. Blinding
In this prospective, blinded study, 100

was done by sealed envelope, which was opened by the attendant, who was accompanying the patient in the hospital. The parameters measured were post procedure pain, rectal tenesmus, recurrence of bleeding and effectiveness of the procedure. [ It is defined as overall satisfaction with the surgical outcome using a visual analogue scale $[0=$ dissatisfied, $10=$ satisfied].

IRC was done at all the three principle positions of hemorrhoids i.e. at 3,7 and 11 'O clock position. RBL was also done at the similar places 9 .

\section{Statistical analysis}

The data was analyzed using Students' unpaired t test. Data were entered in to a database and analyzed using statistical software [Graphpad Quick Calcs, San Diego, CA]. A value of $p<0.05$ was considered statistically significant.

The results of the study are given in Table 2.

TABLE 2 - Results and differences between both methods

\begin{tabular}{cccrcrc}
\hline $\begin{array}{c}\text { Treatment } \\
\text { method }\end{array}$ & $\begin{array}{c}\text { Rectal } \\
\text { Tenesmus }\end{array}$ & $\begin{array}{c}\text { Anal } \\
\text { pain }\end{array}$ & Bleeding & $\begin{array}{c}\text { Vagal } \\
\text { reaction }\end{array}$ & Prolapse & $\begin{array}{c}\text { Effectiveness } \\
\text { of procedure }\end{array}$ \\
\hline IRC [n-48] & 2 & 6 & 16 & NONE & 1 & $83 \%$ \\
RBL[n-52] & 9 & 19 & 9 & 1 & NIL & $90 \%$ \\
$\boldsymbol{P}$ & 0.0001 & 0.0003 & 0.0001 & 0.0028 & 0.0028 & 0.01 \\
\hline
\end{tabular}

\section{Discussion}

1] The infrared coagulator works on the same principle as the $\mathrm{CO} 2$ laser. This method has many advantages ${ }^{10}$ for the treatment of hemorrhoids.

2] Pregnancy is not a contraindication. 5 of the female patients in our study were in their second trimester of pregnancy and were referred by the gynecologist for bleeding per rectum. Earlier medical treatment had failed to control the bleeding. They were found to have internal bleeding hemorrhoids. Infra red coagulation was performed. All of them had an uneventful antenatal period apart from a complete control of bleeding per rectum.

3] Even when repeated several times over, it is a safe and swift procedure.

7] As compared to laser or electro coagulation, injury to bone or periosteum is unknown ${ }^{11}$.

\section{Infrared coagulation vis-à-vis rubber band ligation}

1] Both the treatments [IRC and RBL] are ambulatory.

2] The cost of coagulation is limited to the acquisition of the coagulator, since it does not require any maintenance, except the normal care during disinfections and use. The running cost is minimum and only one new tungsten halogen bulb needed replacement during the last $5 \mathrm{yrs}$ of our use of the instrument.

3] Although, rubber band ligation demonstrated greater long-term efficacy, it was associated with a significantly higher incidence of post treatment pain ${ }^{12}$. In contrast, infra red coagulation is associated with both fewer and less severe complications. The most efficacious therapy, however, may not be the optimal one if the risks of potential complications outweigh the benefits of the treatment ${ }^{13}$. 4] No special training is required to carry out coagulation provided the area of coagulation is kept above the dentate line. While application of band needs training for placing the band at the right place, failing to this can lead to complications like pain, strangulation of pile, necrosis, or even sepsis. The anatomical results following IRC suggests that the progression of hemorrhoids and probably, the need for surgery are prevented ${ }^{14}$.

5] Band ligation is marked by a great number of complications of an inflammatory character ${ }^{15,16}$. In our study, a feedback from the patients who had reported with recurrence of bleeding during the follow up from both the groups i.e. treated either by RBL and IRC was as follows.

a. Patients treated with RBL had experienced pain of a significant amount. This lasted for about a week. With a recurrence of bleeding, they were advised repeat application of band. $90 \%$ of them refused to undergo banding for fear of pain.

b. Patients who underwent IRC for hemorrhoids and reported with recurrence of bleeding were advised for repeat coagulation. With previous experience of almost pain free procedure, $92 \%$ of them readily agreed for the same.

6] Rubber band ligation has been associated with life threatening complications like tetanus, liver abscess, pelvic cellulitis, rectovaginal fistula, and bacteremia. The septic complications are manifested with a clinical triad of pain, fever and retention of urine ${ }^{17,18,19,20,21}$.

7] IRC is effective, inexpensive, and optimally patient-friendly ${ }^{22}$.

8] Infra red coagulation is also well tolerated by the younger patients with hyperactive anal sphincter, where rubber band ligation had reportedly caused conceivable pain after therapy ${ }^{23}$.

9] Pain after RBL occurs more often than previously recognized. It is suggested that informed consent be obtained before RBL and that patients should be given the opportunity to delay treatment if they so wish $^{24}$ 


\section{Infrared coagulation vis-à-vis} cryosurgery and other techniques

1] Cryosurgery is associated with a higher rate of complication and less patient satisfaction $^{25}$. It is almost never justified and is being used but by only a few surgeons.

2] Complications like fissures, bleeding, and rectal spasm had occurred with the bipolar probe, and with the heater probe. The heater probe caused more pain during treatments ${ }^{26}$. These electro surgical equipments are unable to accomplish a spot welding like the IRC. As contrast to true cautery, which causes damage similar to $3^{\text {rd }}$ degree burns ${ }^{27}$, the tissue damage that does occur with IRC is very superficial and is comparable to that which occurs with Lasers. Nevertheless, the amount of tissue destruction caused by electrocautrization is unpredictable.

3]. Sclerotherapy is useful only in early grades of hemorrhoids, and needs a proper placement of injection in the hemorrhoid mass. To achieve such perfection, it requires experience. The technique is often associated with septic complications ${ }^{28}$. Life threatening complications like retroperitoneal sepsis and necrotizing fascitis have been reported after submucosal injection therapy ${ }^{29}$. 'Oleogranuloma' is another complication reported with the sclerotherapy. Such complications are not reported with the IRC.

4] Direct current probe [Ultroid, Hemoron] is also used by some proctologists. But the procedure is time consuming and cumbersome in application. It needs about 10 minutes to deal with a single hemorrhoid and is thus associated with more pain and reduces compliance both on the part of the patient and the operator. The cause of spontaneous, heavy bleeding in four of the patients treated by IRC possibly was due to the sloughing of the pedicle following the coagulation. This alarming complication could be averted if overlapping of the coagulation spots is avoided while coagulating the pedicle.

The post coagulation pain was mostly complained by those patients in whom the hemorrhoids were large in size and coagulation was done too close to the dentate line. The reason for anal pruritus probably was due to hypersensitivity to the ointment used for application. Another contributory factor was the lack of proper local hygiene.A false notion and an anxiety of not disturbing the 'operated' area distracted a few patients keeping the area clean. Appropriate instructions with regards to local cleanliness solved the problem.

Our findings are comparable to those observed by Sorf et al ${ }^{30}$, Novah-El ${ }^{14}$, $\mathrm{O}^{\prime}$ Holleran $^{7}$, Walker et $\mathrm{al}^{10}$ and Johanson ${ }^{13}$.

\section{Conclusion}

The study shows that infrared coagulation could be adopted as an effective alternative to conventional method of pile management as it is quick, hassle free and safe. Save the initial cost of the instrument, there are no expenses of a recurring nature. The application is easy and requires no special training. In comparison, it is better tolerated than the band ligation, and more effective when compared to the other modalities of hemorrhoid treatment in practice.

\section{References}

1. Leff E.Haemorrhoids: current approaches to an ancient problem. Postgrad Med 1987, 82:95-101.

2. Smith LE. Hemorrhoids. A review of current techniques and management. Gastroenterol Clin North Am 1987; 16: 79-91.

3. Arullani A, Cappello G, Diagnosis and current treatment of hemorrhoidal disease. Angiology 1994 Jun; 45(6 Pt 2): 560-5.

4. Nath G, Kreitmaier A, Kiefhaber P et.al. Neue Infrarotkoagulationsmethode.Verhandlungsband des 3 Kongresses der Deutscher Gesellschaft fur Gastroenterolgie.Munchen 1976, S. 17.Erlangen: Permed Verlag.

5. Pfenninger JL, Surrell J, Nonsurgical treatment options for internal hemorrhoids. Am Fam Physician. 1995 Sep 1; 52(3): 82134, 839-41.

6. Leicester RJ, Nicholls RJ, Mann CV. Infrared coagulation: a new treatment for hemorrhoids.Dis Colon Rectum 1981 NovDec; 24(8):602-5.

7. O'Holleran TP, Infra red photocoagulation of hemorrhoids. Nebr Med J 1990 Nov; 75(11): 307-8.

8. Templeton JL, Spence RAJ, Kennedy TL. Comparison of infrared coagulation and band ligation for first and second-degree haemorrhoids. A randomized prospective clinical trial. Br Med J, 1983, 286: 1387-9.

9. Russell TR, Donahue JH. Hemorrhoidal banding: a warning. Dis Colon Rectum1985; 28:291-3.

10. Walker AJ, Leicester RJ, Nichollas RJ. A prospective study of infrared coagulation, injection, and rubber band ligation in the treatment of haemorrhoids. Int J Colorectal Dis 1990; 5:113-6.

11. Dennison AR, Wherry DC, Morris DL. Hemorrhoids: Non-operative management Surg Clin North Am 1988; 68:1401-9.

12. MacRae HM, McLeod RS Comparison of hemorrhoidal treatment modalities. A meta-analysis. Dis Colon Rectum 1995 July; 38(7): 687-94.

13. Johanson JF, Rimm A, Optimal nonsurgical treatment of hemorrhoids: a comparative analysis of infrared coagulation, rubber band ligation and injection sclerotherapy. Am J Gastroenerol 1992 Nov; 87(11): 1601-6.

14. Novah-El. The outpatient management of internal hemorrhoids by infrared coagulation. Rev Med Panama 1993. 18 [3]; 166-70.

15. O'Hara VS. Fatal clostridial infection following hemorrhoidal banding. Dis Colon Rectum 1980; 23:570-1.

16. Nikitin AM, Dul'tsev IuV, Chubarov-Iulu, Iakushin AV, Minbaev ShT. A comparative study of nonsurgical methods in the treatment of hemorrhoids. Khirurgiia-Mosk 1992 Sept-Oct (9-10): 47-50.

17. Wochter DG, Luna GK. An unusual complication of rubber band ligation of hemorrhoids. Dis Colon Rectum 1987; 30:137-40.

18. Shemesh EI, Kodner IJ, FryRD et al. Severe complications of rubber band ligation of internal hemorrhoids. Dis Colon Rectum 1987; 30:199-200.

19. Quevedo-Bonilla G, Farkas AM, Abcarian H.etal. Septic complications of hemorrhoidal banding. Arch Surg 1988:123:650-1.

20. Clay LDIII, White JJ Jr.Davidson JT, et al Early recognition and successful management of pelvic cellulitis following hemorrhoidal banding. Dis Colon Rectum 1986; 29:579-81.

21. Scarpa FJ, Hillis W, Sabetta JR, Pelvic cellulitis: A life-threatening complication of hemorrhoidal banding. Surgery 1988; 103:383-5.

22. Janssen LW. Consensus Hemorrhoidsc (Dutch Society for Surgery) Ned-TijdschrGeneeskd 1994 Oct 15; 138(42): 2106-9.

23. Ambrose N.S, Morris D, Alexander Williams J, Keighley M.R.B. A randomized trial of photocoagulation or injection sclerotherapy for the treatment of first and second-degree hemorrhoids: Dis Colon Rectum 1985, 28:238-40.

24. Hardwick RH, Durdey P. Should rubber band ligation of haemorrhoids be performed at the initial outpatient visit? Ann R Coll Surg Engl 1994 May; 76(3): 185-7.

25. Buls, JG, Goldberg, SM. Modern management of hemorrhoids. Surg Clin North Am 1978; 58:469.

26. Jensen DM, Jutabha R, Machicado GA, Jensen ME, Cheng S, Gornbein J, Hirabayashi K, Ohning G, Randall G. Prospective randomized comparative study of bipolar electro coagulation versus heater 
probe for treatment of chronically bleeding internal hemorrhoids. Gastrointest Endosc 1997 Nov; 46(5): 435-43.

27. Pfenninger JL, DeWitt DE. Radio frequency surgery. Procedures for primary care physicians. $1^{\text {st }}$ Ed. St.Louis: Mosby, 1994; 91-101. Chapter 16, edited by Pfenninger JL and Fowler GC.
28. Barwell J, Watkins RM, Lloyd Davies E, Wilkins DC. Life threatening retroperitoneal sepsis after hemorrhoidal injection therapy: report of a case. Dis Colon Rectum 1999 Mar;42(3):421-3.

29. Kaman-L, Aggarwal S, Kumar R, Behera A, Katariya RN. Necrotizing fascitis after injection sclerothrapy for hemorrhoids: report of a case. Dis Colon Rectum.1999 Mar; 42(3): 419-20.

30. Sorf M, Krislo V, Skovajsova T, Lackovicova V, Ambulatory therapy of internal hemorrhoids using infra red photocoagulation and elastic ligature. Vnitr Lek.1993; 39(1): 38-42. Gupta PJ. Coagulação por raios infravermelhos: opção preferencial para o tratamento de hemorróidas. Acta Cir Bras
[serial online] 2004 Jan-Fev;19(1). Disponível em URL: http://www.scielo.br/acb.

RESUMO - Objetivo: Mostrar os benefícios do uso dos raios infravermelhos como alternativa no tratamento de hemorróidas sangrantes, comparado a outras modalidades habitualmente utilizadas. Métodos: 212 pacientes com hemorróidas sangrantes foram tratados com raios infravermelhos e foram acompanhados por período de 18 meses a fim de se observar os efeitos do procedimento. Comparou-se com outras modalidades usuais de tratamento. Resultados: Apenas 28 pacientes tiveram persistência ou recidiva de sangramento. O procedimento mostrou vantagens comparado a outros. Conclusão: A coagulação de hemorróidas sangrantes nos estágios iniciais por raios infravermelhos mostrou ser uma alternativa simples, eficaz e segura, em comparação a outros procedimentos convencionais. O procedimento é rápido e menos doloroso. Pode ser repetido em caso de recidiva e deve ser considerado como primeira escolha em hemorróidas precoces.

DESCRITORES - Hemorróidas. Raios infravermelhos. Hemostáticos. Assistência centrada no paciente. Procedimentos cirúrgicos ambulatórios.

Conflict of interest: none

Financial source: none

Correspondence:

Pravin J. Gupta

Gupta Nursing Home - D/9, Laxminagar

Nagpur - 440022 - India

Fax:(91)712-547837

drpjg@yahoo.co.in

drpjg_ngp@sancharnet.in 